\title{
Prevalence, intensity, and exposed variables of infection with Acanthocephala parasites of the gastrointestinal tract of Coptodon zillii (Gervais, 1848) [Perciformes: Cichlidae] in Zobe Dam, Dutsin-Ma Local Government Area, Katsina State, Nigeria
}

\author{
Tolulope Ebenezer Atalabi ${ }^{1 *}$, Agnes O. Awharitoma ${ }^{2}$ and Francis Omowonuola Akinluyi ${ }^{3}$
}

\begin{abstract}
Background: Estimate shows that about one billion people rely on fish as primary source of animal protein. Currently, the global record portraying Nigeria as the largest producer of fishes (over 15,489 t per annum) in Africa is being threatened by the presence of various species of parasites that consider fishes as suitable definitive hosts. Control strategies will, however, be ineffective if there are scanty epidemiological data. Based on this premise, we undertook this present study to identify species of parasites, their prevalence, mean intensities, and indicators of infection of Coptodon zillii in Zobe Dam in the study area.

Methodology: Study design was cross-sectional in nature with sample size of 411 fish. The data collected from this study were entered into Microsoft Excel 2010 and analyzed with Epi Info ${ }^{\text {TM }}$ 7. After evisceration and standard histological protocol, recovered parasites were identified as Acanthogyrus tilapiae using standard identification keys.

Results: Major findings of this study show that the overall prevalence and mean intensity of piscine acanthocephaliasis were $16.30 \%$ (12.94-20.31) and 1.46 (1.19-1.72) parasites per Coptodon zillii respectively. Prevalence and mean intensity of Acanthocephala infection significantly increased as the length of fish increased $\left(x^{2}=14.001 ; p=0.0002\right)$ with fish having a length range of $17.0-23.9 \mathrm{~cm}$ being about four times more likely to be infected compared to those with 11.0-16.9 cm length [COR (95\% Cl) 3.78(1.81-7.89)]. In like manner, there was a significant increase in the prevalence of infection as the weight of fish increased $\left(x^{2}=6.055 ; p=0.0139\right)$ with those belonging to weight category $190.1-250.0 \mathrm{~g}$ being three times more likely to be infected compared to those in 70 . 1-130.0 g category [COR $(95 \% \mathrm{Cl}) 3.38(1.05-10.84)]$. Besides, Fulton's condition factor was a major determinant of infection with piscine acanthocephaliasis $\left(X^{2}=13.981 ; p=0.0002\right)$.

Conclusion: Based on the findings of this study, it could be concluded that length, weight, and condition factor were indicators which contributed substantially to piscine acanthocephaliasis in Zobe Dam. In view of reports indicting acanthocephalans as biomarkers of lead $(\mathrm{Pb})$ pollution, further study is, however, recommended to ascertain this hypothesized heavy metal pollution in the study area and its environs.
\end{abstract}

Keywords: Prevalence, Intensity, Piscine, Acanthocephaliasis, Zobe, Dam, Katsina, Nigeria

\footnotetext{
* Correspondence: ebenezer2k2@gmail.com

'Department of Biological Sciences, Faculty of Science, Federal University,

Dutsin-Ma, P.M.B. 5001, Dutsin-Ma, Katsina State, Nigeria

Full list of author information is available at the end of the article
} 


\section{Background}

Fish is the most important single source of high-quality protein which provides around 19\%, 7.6\%, > 11\%, <21\%, and $19 \%$ of animal protein consumed in Africa, North and Central America, Europe, Asia, and LIFDCs [low-income food deficit countries] (including China) respectively (FAO, 2009). While estimate shows that about one billion people rely on fish as primary source of animal protein, global fish consumption was expected to hit the target of 110 million tonnes by 2010 (Tidwell \& Allan, 2001).

Coptodon zillii originates from freshwater in tropical and subtropical Africa, the Near East, and West and East Africa, as well as Israel and Jordan Valley. Adults and fingerlings feed on food materials at the benthic region of shallow waters (Gophen, 2016). Documented evidence shows that spawning season commences in April and ends by August, with many cycles of reproduction annually (Ben-Tuvia, 1978).

Findings have shown that low temperatures induce reduction in its tolerance level to parasites. Hence, this predisposes the fish to infections which, depending on the intensity, may lead to serious pathological changes in the morphology of visceral organs, stunted growth, poor fish quality, and mortality of many which results in huge economic loss to the fish industry (Klinger \& Floyd, 2002; Gophen, 2016). Tilapia zillii, a related species, has been known to be parasitized by different species of parasites, including nematodes, hirudines (Ejere et al., 2014), trematodes (Echi, Eyo, Okafor, Onyishi, \& Ivoke, 2012; Ibrahim \& Soliman, 2010), ciliophorans (Shulman, 1984), trypanosomes (Ahmed, Tawfif, \& Abbas, 2000), and acanthocephalans (Bayoumy, Abd El-Hady, \& Osman, 2006).

Currently, the global record portraying Nigeria as the largest producer of fishes (over 15,489 tonnes per annum) in Africa (FAO, 2007) is being threatened by the presence of various species of parasites that consider fishes as suitable definitive hosts. Control strategies will, however, be ineffective if there are scanty epidemiological data. Based on this premise, we undertook this present study to identify species of parasites, their prevalence, mean intensities, and indicators of infection of Coptodon zillii in Zobe Dam, Garahi community of Dutsin-Ma Local Government Area, Katsina State.

\section{Methods}

\section{Study area}

This study was carried out in Zobe Dam (see Fig. 1) which is located in the southern outskirts of Dutsin-Ma Local Government Area of Katsina State, northwestern Nigeria. A total population of 169,671 (as at 2006 census) whose main occupation is farming as well as animal rearing inhabits the LGA which is
$605 \mathrm{~m}$ above sea level and covers an area of $527 \mathrm{~km}^{2}$ (https://en.wikipedia.org/wiki/Dutsin-Ma). Using Katsina town $(<50 \mathrm{~km}$ from Dutsin-Ma) as a reference point, report shows that between 2005 and 2009, mean annual rainfall reduced sharply from 750.6 to $473.8 \mathrm{~mm}$ while mean maximum temperature did not change significantly-34.2 to $34.5{ }^{\circ} \mathrm{C}$ (NBS, 2011). These probably inform the endemicity of Sudan savanna vegetation type characterized by short, scanty, and scattered trees in the study area.

Completed in 1983 with irrigation potential of $8000 \mathrm{ha}$, a length of $2750 \mathrm{~m}$, and a spillway capacity of $2083 \mathrm{~m}^{3} / \mathrm{s}$ (UNEP, 2005; https://en.wikipedia.org/wiki/ Zobe_Dam), Zobe Dam now serves the purposes of tourism, fishing, and irrigation.

\section{Study design and sample size}

This present cross-sectional study was carried out between November 2014 and April 2015. Four hundred and eleven (411) samples of Coptodon zillii caught with fishing nets were purchased from local fishermen within this period.

\section{Fish biometric data collection and dissection}

Fish samples were transported to the Biology Laboratory of Federal University Dutsin-Ma, where sex and biometric data were recorded. Weight was taken to the nearest $0.01 \mathrm{~g}$ using PGW Precision (capacity: maximum of $120 \mathrm{~g}$; readability: 0.001 to $0.01 \mathrm{~g}$ ) and Nimbus Analytical (capacity: maximum of 450 g; readability: $0.0001 \mathrm{~g}$ ) Balances manufactured by $\mathrm{AE}$ (Adam Equipment) Adam ${ }^{\bullet}$ (United Kingdom) while standard and total lengths were measured to the nearest $0.01 \mathrm{~cm}$ using meter rule and thread. Fulton's condition factor (K) was calculated from fish weight and standard length as described elsewhere ( $\mathrm{Tr}$ ng, Mulder, van Arendonk, \& Komen, 2013). Mechanical stunning method was employed to sacrifice the fish (Biu \& Nkechi, 2013). With the aid of a dissection scissors, a medial line was cut on the ventral part of the fish in longitudinal manner which extended to the cloaca from the neck region. This exposed the internal anatomy. Sex of fish was identified by examining external secondary sexual features and observing the ovaries/testes after dissection on a rectangular board.

\section{Recovery and identification of parasites}

The intestines of the fish were transferred to petri dishes, and longitudinal slits were made to expose the gut content in aqueous medium. Parasites, where present, appeared amidst gut content as milky objects resembling grains of rice. They were examined under Motic $^{\circledR}$ Binocular Microscope (New York, USA) using 


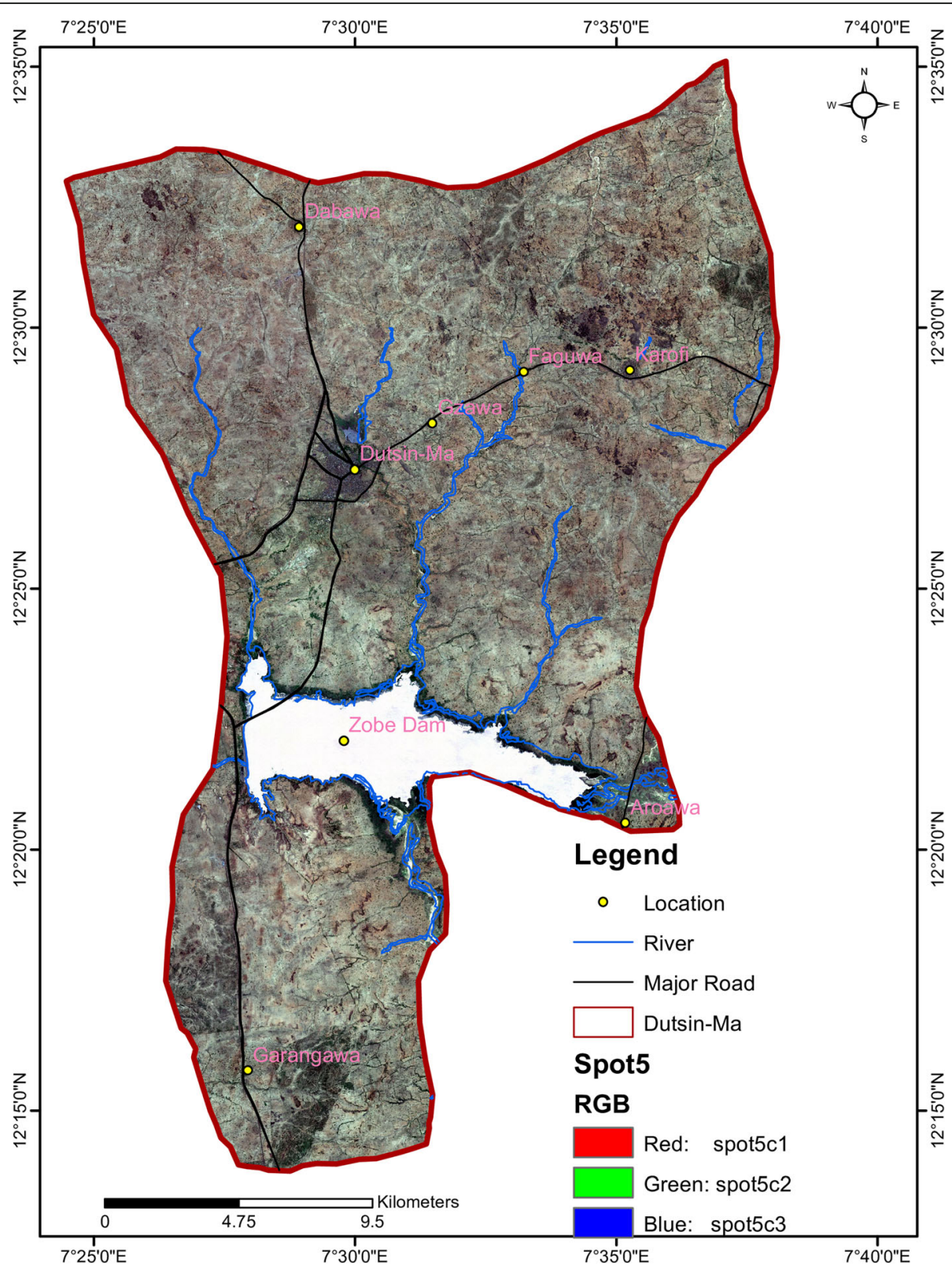

Fig. 1 Map of the study area showing Zobe Dam

$\times 4$ objective. Parasites were subsequently kept in normal saline and transported to the Department of Animal and Environmental Biology, University of Benin, Nigeria, for identification. Parasites were flattened under a cover slip on a microscope slide and fixed and preserved in 10\% formol-saline. Subsequently, they were serially dehydrated in $50,70,90$, and $100 \%$ alcohol respectively. Xylene was used to clear the effect of the alcohol while the worms were stained in aceto-carmine (Carleton, 1980) for less than $30 \mathrm{~min}$. The histological procedure culminated in the use of Canada balsam to prepare permanent mounts. The parasites were identified as Acanthogyrus tilapiae based on the identification keys recommended by Yamaguti, 1963.

\section{Statistical analysis}

The data collected from this study were entered into Microsoft Excel 2010 and analyzed with Epi $\operatorname{Info}^{\text {ta }} 7$. Excel spreadsheet was used to calculate Fulton's condition factor. While descriptive statistics was employed in the analysis of the data obtained, association between exposed variables and the prevalence of infection was determined using chi-square. Prevalence and intensity of infection were computed at 95\% CI (confidence 
interval). The strengths of these associations were measured by means of odds ratio at $95 \%$ CI. Statistical significance was considered at $95 \%$ confidence level (CL) with $P$ value of less than 0.05 .

\section{Results}

The mean \pm standard deviation of total length and weight of the fish sampled were $17.51 \pm 2.59 \mathrm{~cm}$ and $107.49 \pm 37.89$ respectively (see Table 1 ).

It is clear from Table 2 that the overall prevalence and mean intensity of Acanthocephala infection were $16.30 \%$ (12.94-20.31) and $1.46(1.19-1.72)$ parasites per Coptodon zillii respectively. While prevalence was higher in female Coptodon zillii, mean intensity of infection was found to be higher in males. The differences were, however, not statistically significant $(p>0.05)$. Meanwhile, the highest prevalence and mean intensity of infection were recorded among fish with total length ranges of $17.0-23.9 \mathrm{~cm}$ and $11.0-16.9 \mathrm{~cm}$ respectively (see Fig. 2). Invariably, prevalence and mean intensity increased significantly $\left(\chi^{2}=14.001 ; p=0.0002\right)$ as the length of fish increased (see Table 2). Moreover, fish with length range of $17.0-23.9 \mathrm{~cm}$ had odds ratio of 3.78(1.81-7.89).

As shown in Table 3 below, the prevalence of Acanthogyrus tilapiae infection increased insignificantly as the height of fish increased $\left(\chi^{2}=0.165 ; p=0.6843\right)$ while the mean intensity of infection decreased insignificantly as the height of fish increased. Conversely, there was a significant increase in the prevalence of infection as the weight of the fish sampled increased $\left(\chi^{2}=6.055 ; p=0.0139\right)$ while mean intensity of infection increased insignificantly as weight increased. It is worth noting that the odds ratio for fish in the weight group 190.1-250.0 g was 3.38 (1.05-10.84).

\section{Discussion}

In summary, the key findings of this study show that the overall prevalence and mean intensity of Acanthocephala infection were $16.30 \%$ (12.94-20.31) and 1.46 (1.19-1.72) parasites per Coptodon zillii respectively; prevalence and mean intensity of Acanthocephala infection significantly increased as the length of fish increased $\left(\chi^{2}=14.001 ; p=0.0002\right)$ with fish having a length range of $17.0-23.9 \mathrm{~cm}$ being about four times more likely to be infected compared to those with 11.0$16.9 \mathrm{~cm}$ length [COR (95\% CI) 3.78(1.81-.89)]. In like manner, there was a significant increase in the prevalence of infection as the weight of fish increased $\left(\chi^{2}\right.$ $=6.055 ; p=0.0139$ ) with those belonging to the weight category 190.1-250.0 g being three times more likely to be infected compared to those in the 70.1130.0 g category [COR (95\% CI) 3.38 (1.05-10.84)]. Besides, Fulton's condition factor was a major determinant of infection with piscine acanthocephaliasis $\left(x^{2}=13.981 ; p=0.0002\right)$. Based on these, it is obvious that the aims of this present study were achieved.

Reports from different parts of the world have indicated that acanthocephalan parasites are a major threat to the health of fishes (Nabi, Tanveer, Ganaie, Niyaz, \& Abdullah, 2015). In the wild of Kenya and Uganda, findings revealed that Acanthosentis sp., a member of the Acanthocephala group, recorded prevalence values of 7.1 and $10.2 \%$ as well as mean intensities of 1 and 1.6 parasites per Coptodon zillii respectively (Florio et al., 2009). The value of mean intensity obtained in this present study (1.46 parasites per fish) is closely related, suggesting an infection at early stage. Besides, a suspected recent adoption of a suitable intermediate host of acanthocephans as fish bait in the study areas might be responsible for this.

Moreover, in agreement with the findings of this study, previous reports have shown that prevalence and mean intensity of infection increased with the increase in the body size of the fish (Allumma \& Idowu, 2011; Aloo \& Dezfuli, 1997; Goselle, Shir, Udeh, Abelau, \& Imandeh, 2008; Ibrahim, 2012; Saha, Bandyopadhyay, Roy, \& Ghosh, 2015). This did not come as a surprise because larger fishes, with more capacity to consume larger quantity of food, possess longer intestines which in turn absorb more nutrients that are of benefits to parasites. In addition, since size reflects age, old fishes usually have long exposure to parasites compared to young fishes. It is, however, puzzling that the findings of Khalil, El-Shahawy, \& Abdelkader, 2014 contradicted this by asserting that "the larger-sized fish were less affected by infection than the smaller-sized fishes". In agreement with the latter, Biu \& Nkechi, 2013 reported that "smaller Coptodon zillii were more susceptible to parasitic infections than larger ones." This scenario might have been caused by immunological, ecological, or behavioral factors.

Table 1 Descriptive statistics of the biometric data of Coptodon zillii

\begin{tabular}{|c|c|c|c|c|c|c|}
\hline Variable & Mean & Standard error of mean & Standard deviation & Variance & Skewness & Kurtosis \\
\hline Total length $(\mathrm{cm})$ & 17.51 & 0.13 & 2.59 & 6.70 & -1.17 & 3.14 \\
\hline Height $(\mathrm{cm})$ & 6.74 & 0.06 & 1.19 & 1.44 & -0.82 & 1.54 \\
\hline Weight (g) & 107.49 & 1.87 & 37.89 & 1435.69 & 0.42 & 0.42 \\
\hline Fulton condition factor & 0.022 & 0.001 & 0.029 & 0.001 & 9.905 & 104.001 \\
\hline
\end{tabular}


Table 2 Prevalence and intensity of infection by sex and total length

\begin{tabular}{|c|c|c|c|c|c|c|}
\hline Variables & $\begin{array}{l}\text { Number } \\
\text { examined }\end{array}$ & $\begin{array}{l}\text { Number } \\
\text { infected }\end{array}$ & Prevalence (\%) & $\begin{array}{l}\text { Number of } \\
\text { parasites recovered }\end{array}$ & $\begin{array}{l}\text { Mean intensity of } \\
\text { infection }(95 \% \mathrm{Cl})\end{array}$ & $\begin{array}{l}\text { Odds ratio } \\
(95 \% \mathrm{Cl})\end{array}$ \\
\hline \multicolumn{7}{|l|}{ Sex } \\
\hline Males & 243 & 37 & $15.23(10.95-20.37)$ & 55 & $1.49(1.17-1.79)$ & 1 \\
\hline Females & 168 & 30 & $17.86(12.38-24.50)$ & 43 & $1.43(1.16-1.71)$ & $1.21(0.71-2.05)$ \\
\hline Chi square & & & 0.5039 & & & \\
\hline$P$ value & & & 0.4778 & & & \\
\hline Total & 411 & 67 & $16.30(12.94-20.31)$ & 98 & & \\
\hline \multicolumn{7}{|c|}{ Total length $(\mathrm{cm})$} \\
\hline $5.0-10.9$ & 6 & 0 & 0 & 0 & 0 & 0 \\
\hline $11.0-16.9$ & 134 & 9 & 6.72 & 18 & $2(0.73-3.27)$ & 1 \\
\hline $17.0-23.9$ & 271 & 58 & 21.40 & 80 & $1.38(1.22-1.54)$ & $3.78(1.81-7.89)$ \\
\hline Chi square & & & 14.001 & & & \\
\hline$P$ value & & & 0.0002 & & & \\
\hline Total & 411 & 67 & $16.30(12.94-20.31)$ & 98 & $1.46(1.19-1.72)$ & \\
\hline
\end{tabular}

In aquaculture, condition factor is often used as an index of feeding intensity and growth among fishes (Abowei, 2010; Ighwela, Ahmed, \& Abol-Munafi, 2011). Of the four condition factors based on length-mass relationships (Cone, 1989), this present study made use of the Fulton's condition factor which assumes isometric growth of fish (Blackwell, Brown, \& Willis, 2000; Ogamba \& Abowei, 2013; Schmidt-Nielsen, 1984). Table 3 shows that all the infected fish fell within the lowest range of Fulton's condition factor (0.005-0.104).

The interpretation of this is that fishes with low condition factor are more susceptible to parasitic infection and as such not likely to undergo isometric growth. This implies that parasitism has a negative effect on growth. Previously, in Nigeria, parasitized male Clarias gariepinus had been reported to have had a low condition factor, compared to unparasitized ones (Oniye, Adebote, \& Ayanda, 2004). However, findings of a study conducted in England showed that there was no significant difference between the mean Fulton's condition factors of infected and uninfected fish species (Pegg, Williams, Cucherousset, \& Britton, 2011).

Nevertheless, this cross-sectional study is caught in the web of some limitations which the authors hope would be avoided by other researchers in the future. Firstly, the sample size was arbitrarily determined. Secondly, study of

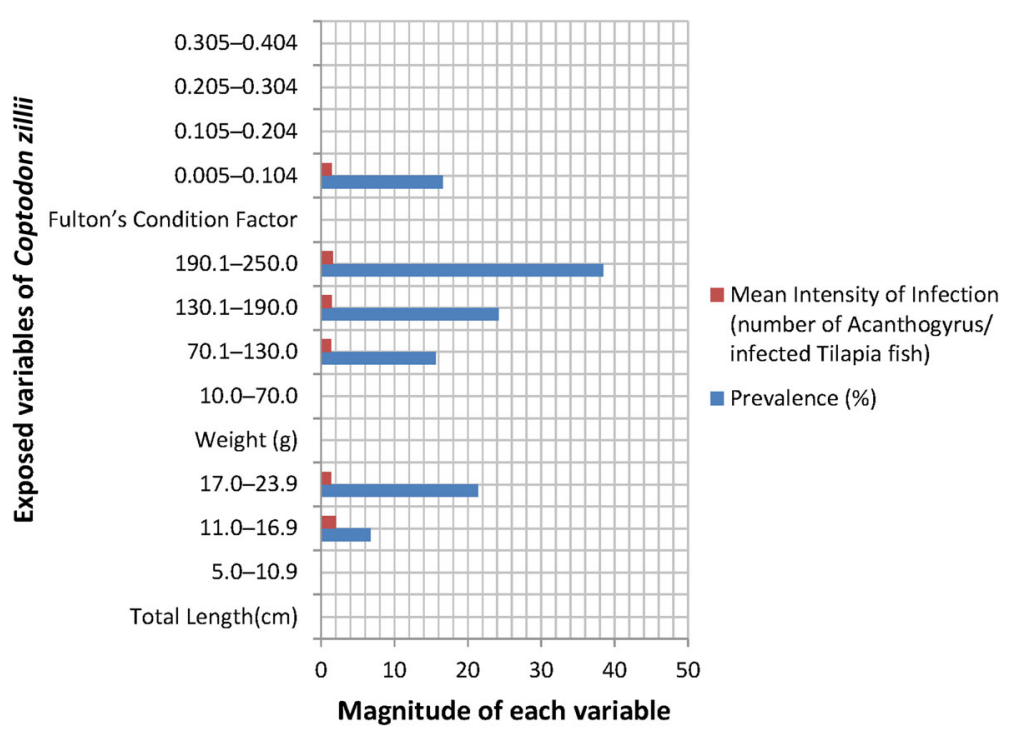

Fig. 2 Bar chart showing the prevalence and intensity of the infection with respect to significant exposed variables 
Table 3 Prevalence and intensity of infection by height, weight, and condition factor

\begin{tabular}{|c|c|c|c|c|c|c|}
\hline Variables & $\begin{array}{l}\text { Number } \\
\text { examined }\end{array}$ & $\begin{array}{l}\text { Number } \\
\text { infected }\end{array}$ & Prevalence (\%) & $\begin{array}{l}\text { Number of } \\
\text { parasites recovered }\end{array}$ & $\begin{array}{l}\text { Mean intensity of } \\
\text { infection }(95 \% \mathrm{Cl})\end{array}$ & $\begin{array}{l}\text { Odds ratio } \\
(95 \% \mathrm{Cl})\end{array}$ \\
\hline \multicolumn{7}{|l|}{ Height (cm) } \\
\hline $1.6-4.5$ & 26 & 2 & 7.69 & 4 & $2(-10.71-14.71)$ & 1 \\
\hline $4.6-7.5$ & 290 & 48 & 16.55 & 70 & $1.46(1.19-1.72)$ & $2.38(0.54-10.41)$ \\
\hline $7.6-10.5$ & 95 & 17 & 17.89 & 24 & $1.41(1.09-1.73)$ & $2.62(0.56-12.14)$ \\
\hline Chi square & & & 0.165 & & & \\
\hline$P$ value & & & 0.6843 & & & \\
\hline Total & 411 & 67 & $16.30(12.94-20.31)$ & 98 & $1.46(1.19-1.72)$ & \\
\hline \multicolumn{7}{|l|}{ Weight (g) } \\
\hline $10.0-70.0$ & 51 & 0 & 0 & 0 & 0 & \\
\hline $70.1-130.0$ & 256 & 40 & 15.63 & 57 & $1.43(1.13-1.72)$ & 1 \\
\hline 130.1-190.0 & 91 & 22 & 24.18 & 33 & $1.5(1.17-1.83)$ & $1.72(0.96-3.09)$ \\
\hline $190.1-250.0$ & 13 & 5 & 38.46 & 8 & $1.6(0.92-2.28)$ & $3.38(1.05-10.84)$ \\
\hline Chi square & & & 6.055 & & & \\
\hline$P$ value & & & 0.0139 & & & \\
\hline Total & 411 & 67 & $16.30(12.94-20.31)$ & 98 & $1.46(1.19-1.72)$ & \\
\hline \multicolumn{7}{|c|}{ Fulton's condition factor } \\
\hline $0.005-0.104$ & 403 & 67 & 16.63 & 98 & $1.46(1.26-1.67)$ & Infinity \\
\hline $0.105-0.204$ & 2 & 0 & 0 & 0 & 0 & \\
\hline $0.205-0.304$ & 0 & 0 & 0 & 0 & 0 & \\
\hline $0.305-0.404$ & 6 & 0 & 0 & 0 & 0 & \\
\hline Chi square & & & 13.981 & & & \\
\hline$P$ value & & & 0.0002 & & & \\
\hline Total & 411 & 67 & & 98 & & \\
\hline
\end{tabular}

probable affinity for a specific intestinal microhabitat by Acanthogyrus tilapiae was not captured by this present survey. Thirdly, the fish samples used in this survey were not blot-dried before they were weighed.

\section{Conclusion}

Based on the findings of this study, it could be concluded that length, weight, and condition factor were indicators which contributed substantially to piscine acanthocephaliasis in Zobe Dam. The baseline information provided by this survey will serve as a guide to future researchers in the study area with respect to sample size determination as well as the expected parasitic fauna of Coptodon zillii. In view of reports indicting acanthocephalans as biomarkers of lead $(\mathrm{Pb})$ pollution (Paller, Resurreccion, de la Cruz, \& Bandal Jr, 2016; Sure, 2003), further study is, however, recommended to ascertain this hypothesized heavy metal pollution in the study area and its environs.

\section{Acknowledgements}

We first and foremost express our profound gratitude to God for keeping us alive to conclude this study successfully. The role of Dr. (Mrs) Adubi Taiwo, Caleb University, Nigeria, in providing useful link for the identification of the parasites recovered in the course of this study is highly commendable.

Availability of data and materials

All the data and materials used to reach the conclusion of this study are available on request.

\section{Authors' contributions}

TEA conceived the study, carried out the laboratory practical, computed and analyzed the data, and drafted the manuscript. AOA identified the parasites recovered. FOA used the software to produce the map of Zobe Dam. All authors read and approved the final manuscript.

\section{Ethics approval}

As at the time this research was conducted, to the best of our knowledge, there was no committee on research ethics involving animals in place. Both at national and institutional level, there were no guidelines on the use of fishes for research (see this link for confirmation: www.fao.org/fishery/ legalframework/nalo_nigeria/en) 


\section{Publisher's Note}

Springer Nature remains neutral with regard to jurisdictional claims in published maps and institutional affiliations.

\section{Author details \\ 'Department of Biological Sciences, Faculty of Science, Federal University, Dutsin-Ma, P.M.B. 5001, Dutsin-Ma, Katsina State, Nigeria. ${ }^{2}$ Department of Animal and Environmental Biology, Faculty of Life Sciences, University of Benin, Benin City, Edo State, Nigeria. ${ }^{3}$ Department of Remote Sensing and GIS, School of Earth and Mineral Sciences, Federal University of Technology Akure, Ondo State, Nigeria.}

Received: 24 October 2017 Accepted: 1 June 2018

Published online: 19 June 2018

\section{References}

Abowei, J. F. N. (2010). The condition factor, length-weight relationship and abundance of Ilisha africana (Block, 1795) from Nkoro River Niger Delta, Nigeria. Advance Journal of Food Science and Technology, 2(1), 6-11.

Ahmed, A. K., Tawfif, M. A. A., \& Abbas, W. T. (2000). Some parasitic protozoa infecting fish from different localities of the River Nile, Egypt. Egyptian Journal of Zoology, 34, 59-79.

Allumma, M. I., \& Idowu, R. T. (2011). Prevalence of gills helminth of Clarias gariepinus in Baga Side of Lake Chad. Journal of Applied Science and Environmental Management, 15(1), 47-50.

Aloo, P. A., \& Dezfuli, B. S. (1997). Occurrence of cystacanths of Polyacanthorhynchus kenyensis larvae (Acanthocephala) in four teleostean fishes from a tropical lake, Lake Naivasha, Kenya. Folia Parasitologica, 44(3), 233-238.

Bayoumy, M. E., Abd El-Hady, O. K., \& Osman, H. A. M. (2006). Site adaptations of Acanthogyrus (Acanthosentis) tilapiae: Observations through light and scanning electron microscopy. Journal of Veterinary Science, 7(4), 339-342.

Ben-Tuvia, A. (1978). Fishes. In: Serruya, C., Lake Kinneret Monographiae Biologicae, 32, Junk Publishers, The Hague, 407-430. https://doi.org/10.1007/ 978-94-009-9954-1_17

Biu, A. A., \& Nkechi, O. P. (2013). Prevalence of gastrointestinal helminths of Tilapia zilli (Gervais 1848) in Maiduguri, Nigeria. Nigerian Journal of Fisheries and Aquaculture, 1(1), 20-24

Blackwell, B. G., Brown, M. L., \& Willis, D. W. (2000). Relative weight (Wr) status and current use in fisheries assessment and management. Reviews in Fisheries Science, 8(1), 1-44.

Carleton, H. M. (1980). Carleton's histological technique, (5th ed., pp. 71-95). New York: Oxford University Press.

Cone, R. C. (1989). The need to reconsider the use of condition indices in fishery science. Transactions of the American Fisheries Society, 118, 510-514.

Echi, P. C., Eyo, J. E., Okafor, F. C., Onyishi, G. C., \& Ivoke, N. (2012). First record of Co-infection of three Clinostomatid parasites in cichlids (Osteichthyes: Cichlidae) in a tropical freshwater lake. Iranian Journal of Public Health, 41(7), 86-90.

Ejere, V. C., Aguzie, O. I., Ivoke, N., Ekeh, F. N., Ezenwaji, N. E., Onoja, U. S., \& Eyo, J. E. (2014). Parasitofauna of five freshwater fishes in a Nigerian freshwater ecosystem. Croatian Journal of Fisheries, 72, 17-24.

Florio, D., Gustinelli, A., Caffara, M., Turci, F., Quaglio, F., Konecny, R., ... Fioravanti, M. L. (2009). Veterinary and public health aspects in tilapia (Oreochromis niloticus niloticus) aquaculture in Kenya, Uganda and Ethiopia. Ittiopatologia, 6, 51-93.

Food and Agriculture Organization. The State of World Fisheries and Aquaculture 2006. Electronic Publishing Policy and Support Branch Communication Division, FAO, 2007, Viale delle Terme di Caracalla, 00153 Rome, Italy. Available at http://www.fao.org/docrep/009/A0699e/A0699e00.htm. Accessed 25 May 2017

Food and Agriculture Organization. The State of World Fisheries and Aquaculture 2008. Electronic Publishing Policy and Support Branch Communication Division, FAO, 2009, Viale delle Terme di Caracalla, 00153 Rome, Italy. Available at https://www.fao.org/tempref/docrep/fao/011/i0250e/i0250e00. pdf. Accessed 25 May 2017.

Gophen, M. (2016). Study on the biology of Tilapia zillii (Gervais, 1848) in Lake Kinneret (Israel). Open Journal of Ecology, 6, 167-175 https://doi.org/10.4236/ oje.2016.64017.

Goselle, O. N., Shir, G. I., Udeh, E. O., Abelau, M., \& Imandeh, G. N. (2008). Helminth parasites of Clarias gariepinus and Tilapia zilli at Lamingo dam, Jos, Nigeria. The Scientific World Journal, 3(4), 23-28.
Ibrahim, M.M. (2012). Variation in Parasite Infra-communities of Tilapia zilli in Relation to some Biotic and Abiotic Factors. International Journal of Zoological Research, 8(2):59-70.

Ibrahim, M. M., \& Soliman, M. F. M. (2010). Prevalence and site preferences of heterophyid metacercariae in Tilapia zilli from Ismalia fresh water canal, Egypt. Parasite Journal, 17, 233-239.

Ighwela, K. A., Ahmed, A. B., \& Abol-Munafi, A. B. (2011). Condition factor as an Indicator of growth and feeding intensity of Nile Tilapia fingerlings (Oreochromis niloticus) feed on different levels of maltose. American-Eurasian Journal of Agriculture \& Environmental Science, 11(4), 559-563.

Khalil, M. I., El-Shahawy, I. S., \& Abdelkader, H. S. (2014). Studies on some fish parasites of public health importance in the southern area of Saudi Arabia. Brazilian Journal of Veterinary Parasitology, 23(4), 435-442.

Klinger R.E. and Floyd, F.R. (2002). Introduction to fresh water fish parasites. Fisheries and Aquatic Science Department, Florida. Cooperative extsio Services, University of Florida. CIR 716 series. Available at https://www.sdstate. edu/sites/default/files/nrm/outreach /pond/upload/Fish-Parasites.pdf. Accessed 25 May 2017

Nabi, S., Tanveer, S., Ganaie, S. A., Niyaz, U., \& Abdullah, I. (2015). Acanthocephalan infestation in fishes-a review. Journal of Zoological Studies, 2(6), 32-37.

National Bureau of Statistics. Annual abstract of statistics, Federal Republic of Nigeria 2011, 698pp. Available at http://istmat.info/files/uploads/53129/ annual_abstract_of_statistics_2011.pdf. Accessed 4 Jan 2017.

Ogamba, E. N., \& Abowei, J. F. N. (2013). An estimation of the size composition and condition factor of Ophiocara porocephala from Amassoma flood plains, Niger Delta, Nigeria. Research Journal of Applied Sciences, Engineering and Technology, 6(3), 366-372.

Oniye, S. J., Adebote, D. A., \& Ayanda, O. I. (2004). Helminth parasites of Clarias gariepinus (Teugels) in Zaria, Nigeria. Journal of Aquatic Sciences, 19(2), 71-75.

Paller, V. G., Resurreccion, D. J. B., de la Cruz, C. P. P., \& Bandal Jr., M. Z. (2016). Acanthocephalan Parasites (Acanthogyrus sp.) of Nile tilapia (Oreochromis niloticus) as biosink of lead (Pb) contamination in a Philippine freshwater lake. Bulletin of Environmental Contamination and Toxicology, 96(6), 810-815.

Pegg, J., Williams, C. F., Cucherousset, J., \& Britton, J. R. (2011). What are the consequences of infection by the introduced parasite Philometroides sanguineus for threatened crucian carp Carassius carassius populations in England? Ecology of Freshwater, Fish, 20, 598-604.

Saha, M., Bandyopadhyay, P. K., Roy, A., \& Ghosh, S. (2015). Impact of seasons, host age, size and sex on the prevalence of protozoan parasites in ornamental fish. IOSR Journal of Agriculture and Veterinary Science, 8(10), 54-59.

Schmidt-Nielsen, K. (1984). Scaling: Why is animal size so important? (p. 241). Cambridge: Cambridge University Press.

Shulman, S. S. (1984). Parasitic Proyozoa. In O. N. Bauer (Ed.), Key to parasites of freshwater fish of USSR, (vol. 1, p. 430). Leningrad: Nauk.

Sure, B. (2003). Accumulation of heavy metals by intestinal helminths in fish: An overview and perspective. Parasitology, 126(7), S53-S60.

Tidwell J.H., \& Allan G.L. (2001). Fish as food: Aquaculture's contribution. EMBO Reports; 2(11):958-963.

Trong, T. Q., Mulder, H. A., van Arendonk, J. A., \& Komen, H. (2013). Heritability and genotype by environment interaction estimates for harvest weight, growth rate and shape of Nile tilapia (Oreochromis niloticus) grown in river cage and VAC in Vietnam. Aquaculture, 384, 119-127.

United Nations Environment Programme (2005). Integration assessment of the impact of trade liberalization- A Country Study on the Nigerian Rice Sector. UNEP/Earthprint; 107 pp. Available at http://www.unep.ch/etb/publications/ intassessment/nigeria.pdf. Accessed 7 Jan 2017.

Yamaguti, S. (1963). Systema Helminthium. Vol. 5, Acanthocephala, New York: John Wiley \& Sons; 423 